\title{
Design-Build Concept In Architectural Education
}

\author{
Branislav Folić, Saja Kosanović, University of Priština \\ Tadej Glažar, Alenka Fikfak, University of Ljubljana
}

\begin{abstract}
Design studio, workshop, practical placement and designbuild concept, are all forms of experiential learning. The aim of this paper is to investigate the significance of design-build concept and to define the extent to which it has penetrated into architectural curricula. Results indicate variety in understanding, programming and implementation among different schools. Conducted comparative analysis of different case examples could be used as a guideline to schools in which this concept has not been introduced yet.
\end{abstract}

Keywords - Community, design-built project, design studio, interdisciplinarity, workshop.

\section{INTRODUCTION: CONCEPT DEVELOPEMENT AND INTERPRETATION}

Many authors link contemporary design-build concept reflected in onsite collaborative work with the methods used in Bauhaus school. In fact, the beginning of the concept in its modern meaning can be considered as happened in Bauhaus. Experiential education in this school was firmly connected to social agenda and technological experimentation so that their interlacing became of primary importance. Workshop focused on fusion of design and craft education with avant-garde artistic practice was at the centre of the curriculum [1, 287]. The workshop teaching was concerned with preparing students for industrial design practice. Regardless of that fact, students were involved in construction of the on campus houses, such as Summerfeld House and Haus am Horn. These houses featured products from the school workshop [1, 288]. In following period, and especially starting from the mid-century, many schools and educational experiments showed a great interest in hands-on architectural approach.

New form of design pedagogy, focused on visualization and characterized by organization of architectural space while also questioning the nature, meaning and intellectual content of architecture, began to emerge in mid-1950s. At the University of Texas, under the deanship of Harwell Hamilton Harris, a group of professors created a new architectural curriculum that was a challenge to École des Beaux-Arts, associated with a derivative classicism and Bauhaus system, which is associated with authentic tradition of modern architecture. The group known as "Texas Rangers" whose members were Colin Rowe, John Hejduk, Bernhard Hoesly and Robert Slutzky, brought critical and formal ideas to various schools, such as Cornell, Syracuse, Cooper Union, or Princeton. New concept of design studio influenced the direction of the design-build concepts which appeared immediately after [2, 282].

During the $1960 \mathrm{~s}$, social component came to the centre of attention, therefore the experiential learning concept in architectural schools of that period aimed to overcome existing social problems. In 1969, for example, the students of Unite Pédagogique 6 (school that emerged after the closure of Beaux-Arts) participated in building the social centre in commune of Portuguese immigrants - Villeneuve-la-Garenne located in suburbs of Paris. The action, seen as one of the most charismatic activities, attracted media attention and encouraged debate. The students built social center by themselves, with the material ordered through the school and intended for practice. The credibility of the action was questioned by some, mostly because the project was carried out for the inhabitants of commune and not with them. That is why the venture of the students of Unite Pédagogique 6 may also be considered as a political action which brought the attention to the oppressed immigrants. Through the project and active participation in building, students strived to overcome urban problems that the city faced. Unintentionally, this was one of the first designbuild projects in architectural education with the contemporary meaning $[3,67]$.

One of the first design-build programs in the United States was founded in the academic year of 1966-1967 as an alternative to studio based culture of learning. During the initial year of the program, students of the Yale School of Architecture, along with other projects, constructed two community centers in Appalachia area that has been under nationwide effort to overcome social problems. American philosopher, sociologist and educational reformer, John Dewey placed experience in the center of learning. "Dewey conceived schools as a social instrument that should harness young people's 'impulses and tendencies to make, to do, to create [and] to produce" [1, 287].

Under the supervision of professors Glen Small and Ahde Lahti, and the chair Raymond Kappe, the first year students of the Department of Architecture of Cal Poly Pomona School of Environmental Design in 1971 developed the project called "Design Lab in the Dunes". The task was to design community for a three day campout and then to test it, and the objectives were to teach students how community functions and how to plan and design in line with nature, man and machine. The first step in the Cal Poly project was to design scale models of the proposed structures which will then be created in corrugated cardboard. Due to material limitations students were forced to make a shape of a structure. Actually, the students were only duplicating the experience which Indians gained already two centuries ago. It was decided to take the previously finished structures down to the isolated beach and create a new town in miniature with high concern for ecology. Students would recycle wastes and work with biodegradable materials where possible. There have been experiments of desalination of sea water and in collecting a solar energy for cooking $[4,18]$. 
In 1967, A Study of Education for Environmental Design, known as Princeton Report, reflected significant change in thinking about the concept of design studio. The report "highlighted the need to broaden the scope of architectural education to the design of the entire built environment and to engage students in solving community-related problems" [5, 282]. These principles were later implemented both through the community-design workshops and designbuilt studios. These two approaches came together in the Rural Studio at Auburn University present since 1992.

\section{CONTEMPORARY DESIGN-BUILD EDUCATIONAL CONCEPT}

Studio work concept developed through many phases over the 20th century. As a derivative studio product, from the first steps, design-build workshops were in most cases following the same path. The variety of design-build concepts in contemporary architectural education has enlarged since the beginning of the 21 st century. Rapidly changing and rather instable socioeconomic and environmental conditions reflect as well on this form of learning, so that the involved groups of students and their tutors today are striving, many times together with communities at different level, to solve the emerging problems of different nature and growing complexity by applying architectural-urban interventions on site. Contemporary design-build projects in architectural schools are characterised by different methods, scopes and outcomes. Considering the transformation of the studio due to uncontrolled use of digital media, design-build projects became one of the last "learning through experience" oases.

Frank Weiner raised an important question of how to overcome studio distractions. "Today the degree and means of destruction have become extreme that the existence of the studio model has become a question. There is also an increasing issue of the personal and the private in the studio. With headphones and access to internet, students escape into their own private world, and have little sense of public obligations" $[6,30]$. The alternatives could be organized team projects that are mostly present in out-of-faculty activities, such as different workshops and design-build events combined in architectural laboratory. This would not mean the abandonment of studio, but a partial transfer to different space.

"Recent technological development has had a powerful impact on both studio pedagogy and studio culture" [5, 283]. The educational turn from the beginning of the 21 st century showed its fallacies after increasing the use of computer drawings at the expense of freehand sketching and creating mockups. It is inevitable that the studio work includes all three means of work and presentation. Many schools today do not allow computers for drawings and presentations on introductory design exercises of the first year of studies, in order to encourage different methods of design process and presentation. In search for the exit towards more experiential students' work, schools are increasingly organizing design-build workshops and other activities that involve group work and communication skills. There are different types of design-build approaches, but all have the same outcome, structure designed and built by students. Under the veil of design-built workshops, schools today realize international connections and work on common projects.

Learning through experience should be implemented through various forms of spatial workshops: urbanistic, architectural, planning, etc. [7, 42]. The scale of the architectural workshop allows to be carried out as a built project on the end of the assignment. Most of design-built projects rely on priory research which is usually done as a part of design studio work. Building process involves hands-on experience which enables students to see real-world consequences of their design decisions.

Design-build studios evolved through the time to become a part of contemporary academic setting. In most of the cases, common features are shared: a division of the course into design and construction phases; partnership between university (college), nonprofit organization and community group; participation by local volunteers; and concentrated effort of students and faculty representatives to raise funds and secure donations for the materials and equipment used in construction [1, 289]. Differences occur in schools involved in projects located in places that are torn by political, social, economic and sometimes ethnic crisis. Design-build studio projects are usually oriented towards better living conditions for community or solving the social issues of vulnerable groups. The type of integration of the design-build studio into curriculum is also an issue that varies from school to school.

\section{CASE EXAMPLES OF CONTEMPORARY DESIGN-BUILD PROGRAMS}

\section{South Africa Ithuba Project}

"The content of the course is important, but equally so the commitment of the lecturer and how the course is taught. This is best illustrated in the case of building a school in the South African Republic by students from the Faculty of Architecture of the University of Ljubljana. This doubtlessly goes beyond the education format prescribed in curricula and accreditation forms and norms; however, this type of work is necessary for constant advancement of education and knowledge in architecture and, most importantly, for continuous improvement of the quality of content of architectural education" [8, 263].

In autumn 2010, twenty senior students and four mentors of Faculty of Architecture in Ljubljana built the library with classroom in Ithuba Skills College complex [9]. This designbuild project lasted through full academic year. In winter semester, the students learned about the African Republic, its history, culture, art and geographic, economic and social features, while the focus in spring semester was moved to project preparation, practical workshops, collection of funds for construction, and the building itself. In mere eight weeks, students and local residents built the building from foundation to the roof, including all equipment. The concept of construction represents contemporary interpretation of 


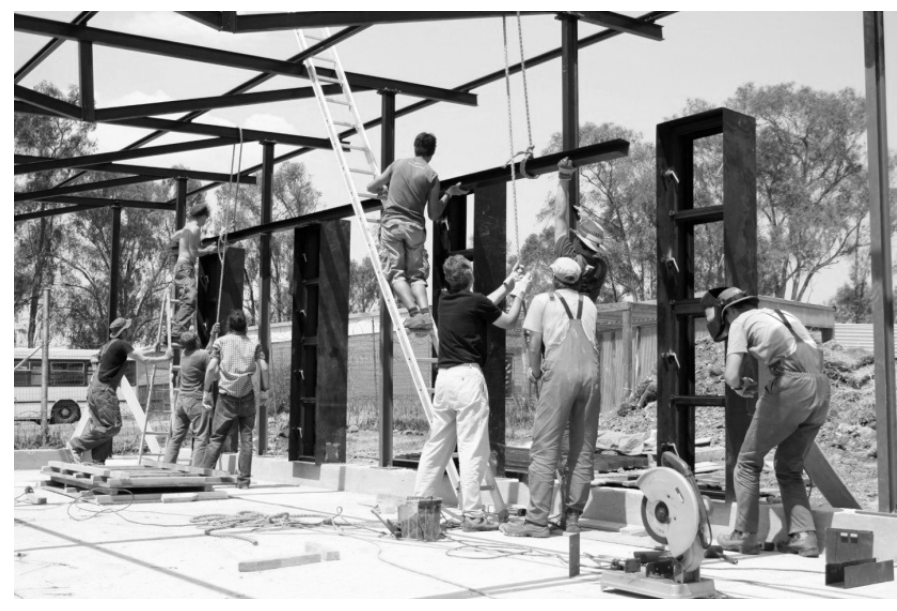

Fig. 1. A school for the future. Ithuba community college South Africa [Photo: Author of the article].

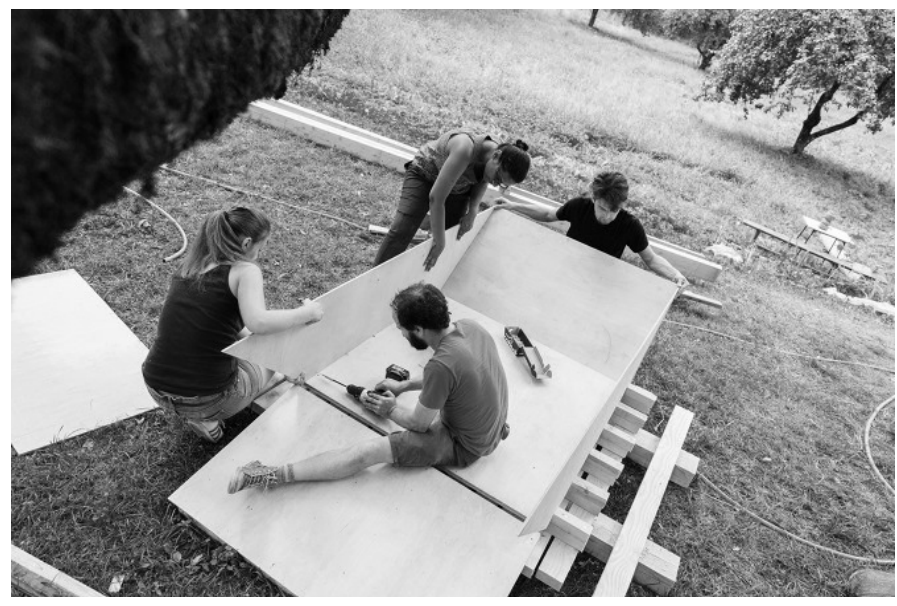

Fig. 2. Get Well City, Sanatorija - Riga Technical University International Summer School [10]

traditional way of construction in Africa, with walls made of clay and straw. A similar principle of preparation, planning, work and on-site construction was used when building of a multi-purpose hall was implemented in 2011 [8, 263].

\section{Riga Technical University International Summer School}

During the last three years, Faculty of Architecture and Urban Planning of Riga Technical University organizes two-week international design-build workshop for students of architecture from different countries. To-date, all workshops were held in a small town Cesis, located in Gauja National Park, the largest protected natural area in Latvia. All three workshops were on design and construction of an installation that deals with improvement of social life, but each has few different themes. For example, in 2014, International Summer School workshop was dedicated to quality of life and health issues. Along with other two different tasks, students built the spa with traditional Latvian sauna [10].

\section{Rural Studio}

Rural studio, established by architect and Professor Samuel Mockbee and Dennis K. Ruth in 1993, is an off campus design-

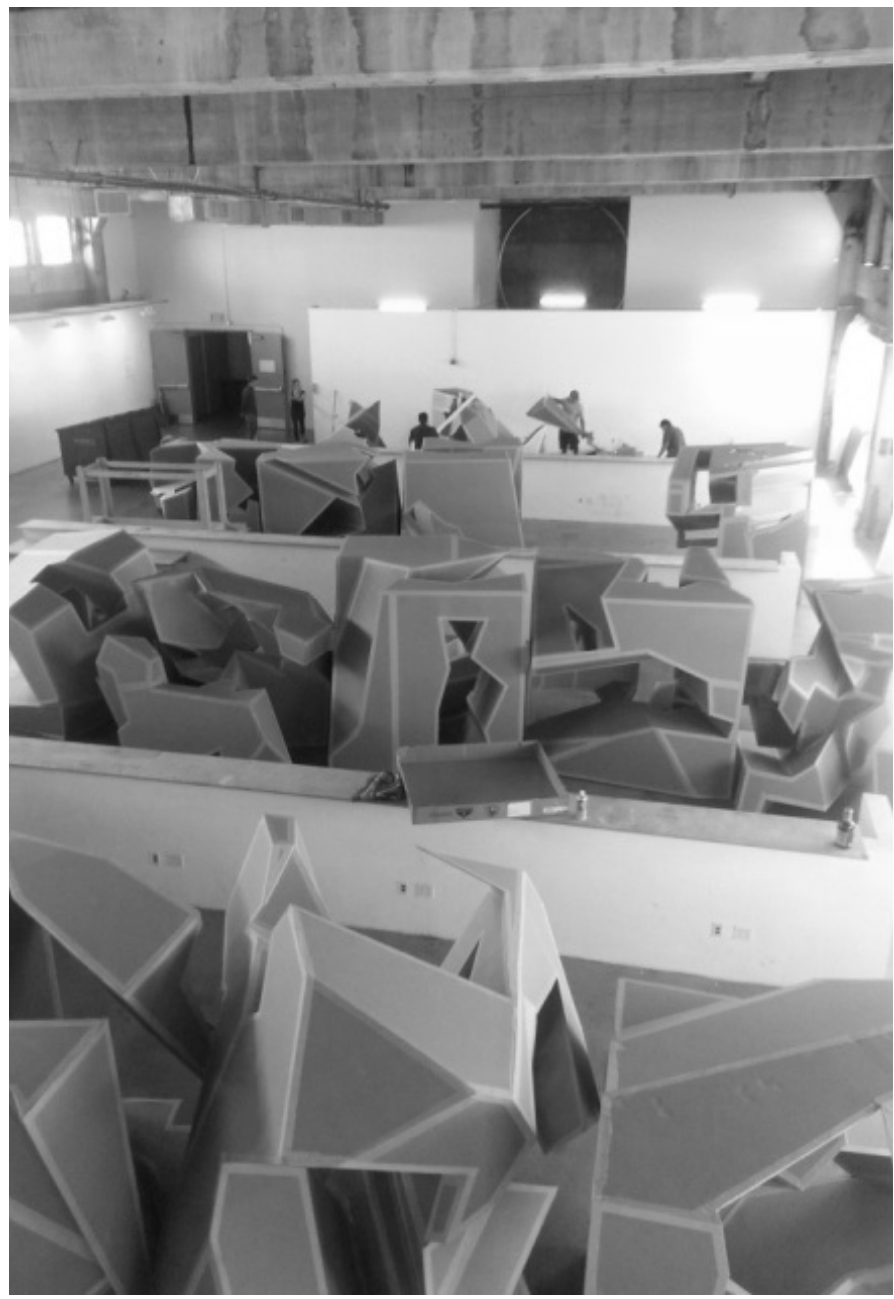

Fig. 3. Making + Meaning - Sci-Arc summer workshop [Photo: Author of the article].

build program of Auburn University. The rural studio is still active under the leadership of Professor Andrew Freear. The students work with community, foundries, design and build projects they developed. By attending series of pedagogic experiments at the studio, the third-year students begin with the individual field research, afterwards they define physical and social factors and the cause of poverty at the location (rural district of Hail in Mississippi). Based on research data, they develop design and later build a relatively small installation for a family residence or for some other purpose of a certain institution. Being at their fifth year of studies, selected students gather once again to finish the group thesis - the project. Working in small teams of 3-5 members gives students a possibility to directly collaborate with the members of the society, to make suggestions, design and build the designed [11].

\section{Washington-Alexandria Architecture Center}

Washington-Alexandria Architectural Center is the urban extension of Virginia Tech's College of Architectural and Urban Studies. Students in this educational institution have the alternative possibility for 'practicing' practice. The design-build 


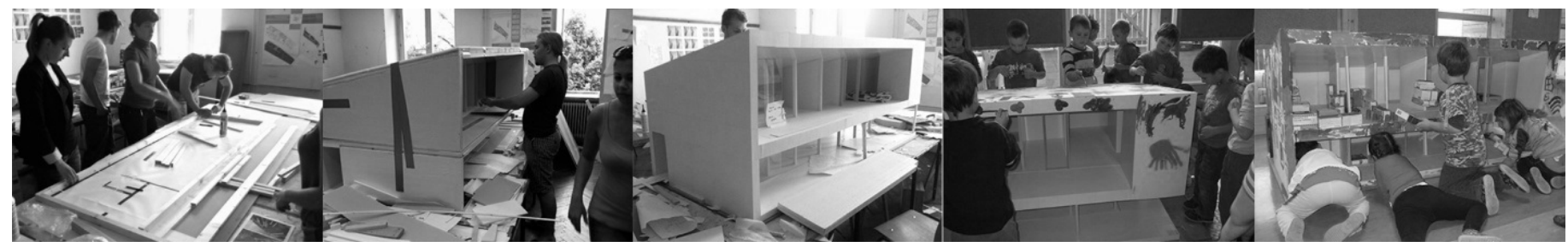

Fig. 4. House built by UL FA students of 2010/2011 design studio, 1:10 scale [Photo: Author of the article].

TABLE I

COMPARISON BETWEEN DIFFERENT DESIGN-BuILD IMPLEMENTED PROJECTS [AUTHORS OF THE ARTICLE]

\begin{tabular}{|c|c|c|c|c|c|c|}
\hline Name of the project & $\begin{array}{l}\text { Year of } \\
\text { implementation }\end{array}$ & $\begin{array}{l}\text { Cooperation and } \\
\text { involvement }\end{array}$ & $\begin{array}{l}\text { Spatial level / } \\
\text { location }\end{array}$ & Project duration & Addressed issue & Achieved outcome \\
\hline $\begin{array}{l}\text { South Africa Ithuba } \\
\text { Project }\end{array}$ & 2010,2011 & $\begin{array}{l}\text { University of } \\
\text { Ljubljana, Faculty } \\
\text { of Archtiecture }\end{array}$ & $\begin{array}{l}\text { Ithuba, South } \\
\text { Africa }\end{array}$ & $\begin{array}{l}\text { Studio work: } \\
\text { On site: } \\
\text { Two months }\end{array}$ & Skill college classroom & $\begin{array}{l}\text { Built project } \\
\text { School classroom }\end{array}$ \\
\hline $\begin{array}{l}\text { International Summer } \\
\text { School }\end{array}$ & $\begin{array}{l}2012,2013, \\
2014\end{array}$ & $\begin{array}{l}\text { RTU Faculty of } \\
\text { Architecture and } \\
\text { Urban Planning in } \\
\text { Riga, } \\
\text { Local community }\end{array}$ & $\begin{array}{l}\text { Each year } \\
\text { different } \\
\text { communities } \\
\text { in Latvia }\end{array}$ & $\begin{array}{l}\text { Lecture, } \\
\text { discussion and } \\
\text { workshop: } \\
\text { Two weeks }\end{array}$ & $\begin{array}{l}\text { Outdoor installation } \\
\text { (book shelter, miniature } \\
\text { sanatoria etc.) }\end{array}$ & Built structure \\
\hline Rural Studio & 1992 to this day & Auburn university & $\begin{array}{l}\text { Multiple } \\
\text { locations in } \\
\text { Hale county, } \\
\text { Alabama, USA }\end{array}$ & $\begin{array}{l}\text { One year design } \\
\text { studio }\end{array}$ & Social & Built home or civic building \\
\hline $\begin{array}{l}\text { Washington- } \\
\text { Alexandria } \\
\text { Architecture Center }\end{array}$ & $\begin{array}{l}\text { Early } 1990 \text { s to } \\
\text { this day }\end{array}$ & Virginia Tech & $\begin{array}{l}\text { One location } \\
\text { Alexandria, } \\
\text { Virginia, USA }\end{array}$ & $\begin{array}{l}\text { Purposely } \\
\text { undefined }\end{array}$ & $\begin{array}{l}\text { School premises and } \\
\text { space }\end{array}$ & $\begin{array}{l}\text { Built furniture, structures } \\
\text { etc. }\end{array}$ \\
\hline $\begin{array}{l}\text { Ghost architectural } \\
\text { laboratory }\end{array}$ & 1994 to this day & $\begin{array}{l}\text { Over } 30 \text { schools } \\
\text { from all across } \\
\text { north America and } \\
\text { Europe }\end{array}$ & $\begin{array}{l}\text { One location } \\
\text { Lower } \\
\text { Kingsburg, } \\
\text { Nuova Scotia }\end{array}$ & $\begin{array}{l}\text { Research: one } \\
\text { week } \\
\text { On site: one } \\
\text { week }\end{array}$ & $\begin{array}{l}\text { Any kind of proposed } \\
\text { structure }\end{array}$ & Built structure \\
\hline Making + Meaning & 2014 & $\begin{array}{l}\text { Southern } \\
\text { California Institute } \\
\text { of Archtiecture }\end{array}$ & $\begin{array}{l}\text { Sci arch, Los } \\
\text { Angeles, USA }\end{array}$ & Five weeks & Spatial experiment & $\begin{array}{l}\text { Built cardboard spatial } \\
\text { structures }\end{array}$ \\
\hline Model house & $2010 / 2011$ & $\begin{array}{l}\text { University of } \\
\text { Ljubljana, Faculty } \\
\text { of Architecture; } \\
\text { Kinfergarten } \\
\text { Šentrupert }\end{array}$ & Ljubljana & Four weeks & House & Built model \\
\hline
\end{tabular}

program is oriented towards students' attempt to define their own space of learning by constantly adding new and renovating old facilities of the faculty premises. Typical correspondence between the end of the project and the end of the academic term is absent. Even more, students work on the project that may be finished by other colleagues. Biannually presented at exhibition, the work is understood as continuous, in progress; the project may evolve further, which presumes that it is not final $[12,52]$. "To think of work of architecture as projection, rather than a complete prescription, allows adequate space for the architect (or student) to simultaneously advance the work while keeping it open for future discovery" $[12,53]$. This is, hence, the alternative to the method where project deadline and all necessary steps, from schematic design, through construction documentation preparation, to building, are defined.

\section{Ghost architectural laboratory}

Studios, together with design-build concept merged into an often seen model of design laboratory. The model, however, may be implemented only if the school has a proper studio space where students work on their projects uninterruptedly. In many examples, a city is taken as a laboratory space. Ghost architectural laboratory started as an alternative to a criticized design curriculum at the beginning stage of architectural education. Its founder Brian MacKay-Lyons said: "I almost quit architecture school after I started. I went into architecture thinking that it would deal with the landscape, with making things, with community, which it didn't. The streets outside was more interesting than what was going on in the studio" $[13,13]$. MacKay-Lyons used it as an argument to start a two-week summer design-built lecture and project in farmland that he owned in Lower Kingsburg in Nova Scotia. "He was criticizing 
the academy way of teaching in the studio. He is promoting a one room schoolhouse approach, in which there would be just three courses: one about place, dealing with environment, one about craft, addressing technology, making, and material culture; and one about community, including clients, culture, and social agency." $[13,13]$. Ghost architectural laboratory is a more unconventional concept of combination of studio teaching with environmentally and technologically based design-built issue.

\section{Making + Meaning}

Southern California Institute of Architecture (SCI-Arc) offers Making + Meaning: a five-week summer program, which introduces the principles of spatial experimentation and design methodologies through the creative processes of architecture. During this program students learn to balance intuitive responses with the need to clearly present their work to a jury and public. Furthermore, this creative course is supported by a series of seminars focused on exploration of technology and fabrication techniques, architecture history and critical thinking, design methodology and contemporary architectural production. Attendance is open for students of different disciplines that are related with architecture. At the end of the term, students produce a Group Exhibition open to the public [14].

\section{Model house}

For schools that cannot implement large-scale design-build workshops the project of the UL FA students is a good example. During academic year 2010/2011 students designed and built a contemporary house in the micro scale of $1: 10$. This house was, in its first phase, was built to understand the meaning of details and different layers of each wall/pavement/ceiling/roof. After the end of the year exhibition the students offered the model to a group of children from kindergarten in Šentrupert (Slovenia). During the second phase children re-modelled the house with their surface interventions and today it is still in use as a doll house.

\section{COMPARATIVE ANALYSIS OF CASE EXAMPLES}

To examine to which extent the design-build concept penetrated in contemporary architectural education, different examples of recently conducted design-build projects were analysed (Table 1). The comparative analysis is based on established criteria which aim to show the scope, engagement and the achieved outcome of the action. The criteria are as follows: cooperation and involvement (with other higher education institutions, community, industry, non-profit organisations, etc.); spatial level (local, regional or international); project duration; the addressed issue (design problems, social issues, ecological aspect, multi/aspect approach, etc.); and the achieved outcome (valued, before all, on the basis of the achieved technical result).

\section{Cooperation and involvement.}

Design-build projects range from the individual design studio work guided by tutor, through project organized by school itself, community, industry, other institutions, economy, complex design-build partnerships between industry, nonprofit organizations and universities. International design-built workshop projects with involvement of two or more schools are common nowadays

\section{Spatial level}

Significant category in design-built projects, which affects the definition of many important aspects, is the place, i.e. the physical frame in which a project will be implemented. As seen in the analysis, the place could be an institution (school of architecture), selected local public or private space, remote area, such as countryside or any other location within one country, international, intercontinental etc. When the venue is limited within the school space, students work on smaller scale projects (Fig. 4).

\section{Project duration}

Duration of a project depends on the developing phases and complexity of the project. It is usually divided in three phases: research, design and building. Apart from the design-build studio, projects are usually set to be implemented during the summer and out of regular school curriculum schedule. Often defined on individual initiative, project duration ranges from two week design-build workshop to one year design-build studio. In some cases project duration is undefined and may last for generations.

\section{Addressed issue}

Addressed issues of the project are different and they involve many problem areas that are not purely associated with design pedagogy, but implement many different disciplines. Project problems could be oriented towards pure design problems, solving social issues, building technology (with research), ecological aspect, comprehensive multi-aspect approach, etc. Most of them deal with all mentioned issues but the main problems are highlighted and set as priority. Lately, most of the workshops deal with the sustainability issues.

\section{Achieved outcome}

Project outcome may be completed or uncompleted (design-built project in progress, continued by next generation of students) object. These projects have different technical outcomes: temporary installation used by community, permanent installation used by community, small scale building that is used by the targeted group, urban furniture elements, structure that may be implemented in different settings, construction experiments, etc.

\section{CONCLUSION}

The research conducted and presented in this paper identifies the types of design-build concepts in architectural education, focusing on contemporary trends. Originally introduced with priority educational motives, research shows that the objectives of design-built projects have much wider significance. 
The outcomes are delivered to local, regional or international communities in the form of developing or developed projects. Selection of the topic and location, planning and implementation of design-build project, limitation of its scope, definition of the size of the resulting object, as studied examples show, vary so much, that it seems as very hard to classify the method in subgroups. Therefore, every design-build venture could be considered as unique methodological path leading to unique artefact.

But, on the other hand, there is one common feature: conducting of priory research, common to all design-build projects. The relation of the concept with research activity accounts for important step in reaching the final, traced product.

From pedagogical point of view, all design-build projects strive to engage students of architecture in critical thinking, problem solving and decision making. Design-build projects show a direct connection between creative, experiential work and interdisciplinarity [8, 258].

The presented variety shows different methodological approaches, but each has important educational qualities. In schools with more modest capacity (in terms of size, funding, etc.), the implementation of design-built concept is rather achievable if done in partnership with school.

Research of recent design-built examples shows a turn in the educational approach where "design studios are more likely than ever to become hybrid workspaces filled with two and three dimensional investigations and equipment, processes and products of both manual and digital work." [15, 284] In this sense, and even thought that many design-built projects are done as extracurricular activities at the moment, there is a tendency towards making a design-build studio.

\section{REFERENCES}

1. Hayes, R.W. Design/Build : Learning by constructing. Architecture School : Three centuries of Educating Architects in North America [J. Ockman, ed.]. Cambridge, London: MIT Press, 2012, pp. 286-290.

2. Simon, M. Design Studio. Architecture School: Three centuries of Educating Architects in North America [J. Ockman, ed.]. Cambridge, London: MIT Press, 2012, pp. 276-85.

3. Folić, B. The role of Henri Lefebvre and the Utopie Group in the Closure of Beaux-Arts : Their Activity in France in 1960s [V. Radonjanin \& N. Folić, ed.]. PHIDAC 11 - III International Symposium for students of doctoral studies in the field of Civil Engineering, Architecture and Environmental protection, Novi Sad, 21-23. septembar 2011. Novi Sad: Faculty of Technical Sciences, 2011, pp. 61-68.

4. Mac Masters, D. Design Lab in the Dunes, LA Times "HOME"(addition to newspaper), July 25,1971 , pp. 17-19.

5. Madlen, S. Design Pedagogy : Changing Approaches to Teaching Design. Architecture School - Three centuries of Educating Architects in North America [J. Ockman, ed.]. Cambridge, London: MIT Press, 2012, pp. 276-284.

6. Weiner, F. Five critical horizons for Architectural Educators in an Age of Destruction. EAAE prize 2003-2005, Writings in Architectural Education [Ebbe Harder, ed.]. 2005, pp. 21-46.

7. Fikfak, A. Workshops as a Form of Empirical Learning : Researching the Term "Sustainable Development" [P. Gabrijelčič \& A. Fikfak, ed.]. The Creativiti Game : Urban Design Workshops, Urban-Architectural Workshops and Spatial Planning Workshops. Ljubljana: Fakulteta za Arhitekturo, 2012, pp. 41-54.

8. Glažar, T. Graditi skupaj, učiti se skupaj [A. Fikfak, ed.]. Book of Abstracts from the First Slovenian Conference on Medicine Architecture and Urban Design - Man and Space, Goriška Brda, Slovenija, 11-12 October 2013. Ljubljana: Fakulteta za Arhitekturo, 2013, p. 30.

9. Vodopivec, A., Planišček, A., Glažar, T., Konstantinovič, J., Skubic, B. School for the future : classroom and library, Ithuba Skills College, Johannesburg : South African Republic. Ljubljana: Fakulteta za arhitekturo, 2011. $78 \mathrm{p}$

10. Get Well City, Sanatorija [online]. Riga Technical University International Summer School [cited 08.09.2014]. http://www.rtusummerschool.lv/ Sanatorija

11. Salomon, D. Experimental Cultures : On the End of Design Thesis and the Rise of the Research Studio. Journal of Architectural Education, Vol. 65, No. 1 (2011) pp. 33-44. http://dx.doi.org/10.1111/j.1531314x.2011.01172.x

12. Foote, J. Design-Build :: Build-Design. Journal of Architectural Education, Vol. 66 (2012), pp. 52-58. http://dx.doi.org/10.1111/j.1531314x.2011.01197.x

13. Fisher, T. Seeing the world whole, Journal of Architectural Education, vol. 65 , No. 2 (2012), pp. 13-16. http://dx.doi.org/10.1111/j.1531314x.2011.01193.x

14. Making + Meaning [online]. Sci-Arc summer workshop [cited: 08.09.2014]. http://www.sciarc.edu/portal/programs/making_meaning/ index.html\#section1

15. Anthony, K. H. Studio Culture and Student Life - A World of Its Own. Architecture School - Three centuries of Educating Architects in North America [J. Ockman, ed.], Cambridge, London: MIT Press, 2012, pp. $398-401$

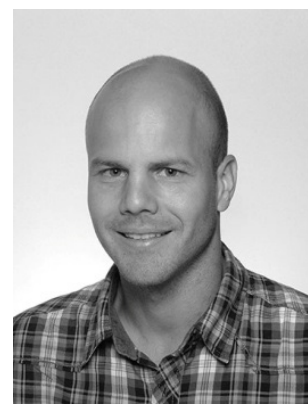

Branislav Folić obtained his $\mathrm{PhD}$ in Architecture and Urbanism in 2015 and the M. Arch. degree in 2005 from the Faculty of Architecture, University of Belgrade.

He is a Assistant Professor at the Department of Architecture of Faculty of Technical Sciences of University in Priština in Kosovska Mitrovica. He runs exercise classes on visual research and architectural design including studio work. He studied two years at Mt. SAC in Los Angeles, where he was awarded $2^{\text {nd }}$ place by AIA at a students' design competition. In 2004, he undertook an internship at the company PTE Architects, London. He is an Associate at the winning project for representing Serbia at the $11^{\text {th }}$ International Architecture Exhibition in Venice, 2008. He won the 3rd prize in the international architecture competition for Silver Lake hotel in east Serbia. $\mathrm{He}$ is a practicing architect. His research interests are architectural and urban design and architectural education.

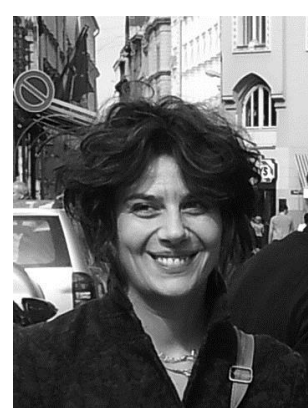

Saja Kosanović obtained her $\mathrm{PhD}$ in Architecture and Urbanism in 2012 and the degree of M.Sci in Architecture and Urbanism in 2007 from the Faculty of Architecture in Belgrade She obtained the degree of M. Arch. from the Faculty of Architecture and Civil Engineering of University of Priština in 2000.

She is an Assistant Professor with the Department of Architecture of Faculty of Technical Sciences of University in Priština in Kosovska Mitrovica. She is a visiting professor with the Faculty of Architecture in Belgrade. She lectures in architectural design, sustainable architecture and urbanism, environmental assessment of buildings, as well as tutors design studio work. She is the author of the national system for environmental assessment of singlefamily houses. She has written the book Environmentally friendly buildings introduction to planning and design (Beograd: Zadužbina Andrejević, 2009). 
Her research interests are architectural design; environmental impacts of buildings; sustainability assessment methodologies, sustainable architectural and urban strategies, planning and design, architectural education. She is a practicing architect.

She is a member of editorial/scientific boards of several journals and scientific conferences.

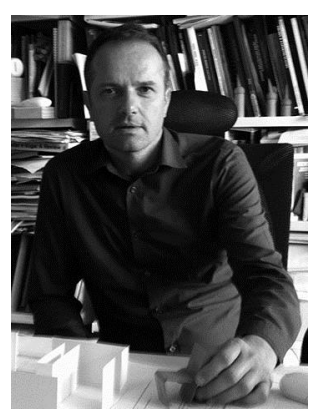

Tadej Glažar received the degrre of MA in Architecture from the Berlage Institute in Amsterdam in 1992, and obtained the title of Graduated Architect from the Faculty of Architecture of University of Ljubljana in 1989. $\mathrm{He}$ is an Associate Professor with the Faculty of Architecture of University of Ljubljana. He holds lectures in architectural design and public buildings and tutors studio design work. Every year he is a tutor at numerous domestic and international workshops and summer schools. He has been working for more than 15 years as an assistant tutor with students of the Faculty of Architecture, University of Ljubljana, and from 2005, of Erasmus students from Spain, Portugal, Belgium, Slovakia and Italy. He is a visiting lecturer and studio critic at TU Graz, Ecole Nationale Supérieure d'Architecture de Nantes, Građevinsko arhitektonski fakultet Split, ZHAW Winterthur, Arhitektonski fakultet Zagreb, ETH Zurich. He has organised and participated with students at several architectural and urbanistic workshops and made presentations and exhibited the work in Slovenia and abroad. His research interests are urban and architectural design, sustainable urban development strategies, housing and public space, architecture of public and apartment buildings, architectural education. He is a practicing architect. He is the author of numerous architectural and urban projects and has received national and international prizes.

$\mathrm{He}$ is a member of editorial board of magazines Oris (Zagreb, Croatia) and Werk, Bauen und Wohen (Zurich, Switzerland). He is also a member of Scientific Board for Tourism at Croatian Academy of Sciences and Arts. He is a Jury advisor for European Union Prize for Contemporary Architecture - Mies Van Der Rohe award.

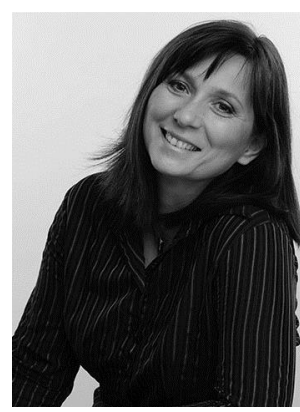

Alenka Fikfak received her PhD in 2004, M. Sci in 1997, and the title of Graduated Architect in 1992 from the Faculty of Architecture of University of Ljubljana.

She is an Assistant Professor with the Faculty of Architecture of University of Ljubljana (UL FA) She holds lectures in architectural design, urban design, rurism and rural architecture, rura planning, settlement culture, as well tutors design studio work. She is Head of Chair of Urbanism UL FA, Head of UL FA Management Board, a member of Chamber UL FA. She has organised and participated with students at several architectural and urbanistic workshops for different local communities in Slovenia population of the students work on the local level. Her research interests are spatial and landscape planning, planning of small settlements, regulatory plans for the regulation of non-urban settlements, evolutionary constants of a settlement culture undergoing renovation, with particular reference to the coastal region, models for revitalisation of degraded landscape areas, analysis of trends of spatial development, architectural education. She was heading the process of accreditation of study programs in urbanism (bachelors and masters) in 2010-12, and re-accreditation (unified masters) study program in architecture in 2012-13. She has been a participant and a coordinator of different EU projects / programmes. She has been an organizer of national and international conferences on spatial planning, development and urbanism.
CONTACT DATA

\section{Branislav Folić}

E-mail: branislav.folic@pr.ac.rs

\section{Saja Kosanović}

E-mail: saja.kosanovic@pr.ac.rs; kossanovic@gmail.com

\section{Tadej Glažar}

E-mail: Tadej.Glazar@fa.uni-lj.si

\section{Alenka Fikfak}

E-mail: Alenka.Fikfak@fa.uni-lj.si 